\title{
BETWEEN PRAGUE AND PIRNA A STORY FROM THE BEGINNING OF THE THIRTY YEARS' WAR
}

\author{
JAN BAŤA \\ Univerzita Karlova v Praze
}

\begin{abstract}
Izvleček: Razprava obravnava dva polifona vira s preloma 16. stoletja (CZ-Pu, 59 E 9726/1-3 (olim XXXIII C 20) in D-Dl, Mus. Pi. 2), ki ju lahko povezujemo s češkim humanistom in glasbenikom Nicolausom Dionysiusom (ok. 1577-1647). Ta je bil zaradi svoje luteranske vere leta 1627 izgnan iz češkega kraljestva v Pirno na Saškem. Povzeta sta življenje in delo Dionysiusa in obravnavana njegova vloga pri transferju dveh glasbenih del iz Prage v Pirno med tridesetletno vojno.
\end{abstract}

Ključne besede: Češke dežele, Nicolaus Dionysius Beronensis, zgodovina glasbe, polifoni viri, tridesetletna vojna.

\begin{abstract}
This paper considers two polyphonic sources from the turn of the seventeenth century (CZ-Pu, 59 E 9726/1-3 (olim XXXIII C 20), and D-Dl, Mus. Pi. 2), which are linked to the Bohemian Humanist and musician Nicolaus Dionysius (ca. 1577-1647), who was expelled from the Kingdom of Bohemia to Pirna, Saxony, in 1627 because of his Lutheran faith. This paper summarizes Dionysius's life and works and discusses his role in the transportation of these two musical sources from Prague to Pirna during the Thirty Years' War.
\end{abstract}

Keywords: Czech Lands, Nicolaus Dionysius Beronensis, history of music, polyphonic sources, Thirty Years' War.

The identification of the provenance of sources is one of the most important tasks for a historian of music. Today the location of a large quantity of musical prints and manuscripts across Europe is, however, different from their places of origin. The aim of this article is to trace the itinerary of two musical sources that once constituted part of the same private collection but are now separated by a distance of two hundred kilometres. Both sources are connected with the Lutheran Church of the Holy Saviour in the Old Town of Prague that recently celebrated the four hundredth anniversary of its solemn opening on 5 October 1614.

The construction of the Church of the Holy Saviour between 1611 and 1614 marked the culmination of the emancipation of the Prague Lutherans. They had to wait for this moment for almost a century until 9 July 1609, when Emperor Rudolph II issued his Letter of Majesty on religious freedom. Until then only two Christian denominations had been officially tolerated in the Czech Lands: first, Roman Catholicism and, second, Utraquism, 
as heir to the conservative Hussite movement. ${ }^{1}$ The Lutheran celebration of the issue of the Letter of Majesty on religious freedom took place a few days later (15 July 1609) in the Utraquist Church of the Holy Cross in the Old Town. The ceremony was celebrated with great solemnity and attended by thousands of believers. Almost immediately after the celebration Prague's Lutherans began to apply for financial support for the building of their own church in the Old Town. ${ }^{2}$ After two years of preparatory work the cornerstone of the Church of the Holy Saviour was laid in the presence of religious, secular and academic dignitaries and hundreds of members of the Lutheran community. The ceremony took place on 27 July 1611 at the Church of the Holy Cross. The building of the Church of the Holy Saviour was successfully completed despite financial difficulties, and on Sunday, 5 October 1614 the church was opened with great solemnity, again with the participation of many important guests. The Church of the Holy Saviour, as well as the neighbouring school for boys, developed into an important devotional and intellectual centre of the Lutheran Reformation in the Old Town of Prague. ${ }^{3}$ During the same period the Lutheran community in the Lesser Town also built its own church, dedicated to the Holy Trinity. ${ }^{4}$

The period of devotional liberty guaranteed by the Letter of Majesty of 1609 on religious freedom lasted only eleven years. After the Catholic restoration of 1620 the Church of the Holy Saviour was closed, in 1622, and Lutherans had to leave the Bohemian Lands, mostly going into exile in Saxony. Three years later the Catholic order of Saint Francis of Paola initiated a new period in the history of this church.

Let us now turn our attention to the two sources mentioned at the beginning of this article. The first is a convolute of three alto partbooks from the collection Promptuarium musicum compiled by the cantor in Speier, Abraham Schadeus (1566-1626). ${ }^{5}$ These three collections contain over three hundred compositions by almost one hundred authors and played an important role in the dissemination of double-choir sacred music across the European continent at the beginning of the seventeenth century. ${ }^{6}$ These three alto partbooks are held by the Department of Music of the National Library of the Czech Republic in Prague $(\mathrm{CZ}-\mathrm{Pu}){ }^{7}$ The convolute of the above-mentioned prints contains a manuscript

1 For the sake of non-Czech readers references to literature in the Czech language have been restricted to an indispensable minimum, preference being given to studies in German or English. Studies published in Czech usually include a summary in German or English. I am grateful to Pat Lyons for his generous revision of the final text.

For further information on the history of the Czech Lands during the fifteenth and sixteenth centuries, see Pánek et al., History of the Czech Lands, 149-229. The religious milieu is discussed in David, Finding the Middle Way.

2 See Schreiber, Das Spenderbuch.

3 The history and architecture of the church are described in Wenzel, "Konfese a chrámová architektura," pt. 1. A survey of the history of the Lutherans in the Czech Lands is presented in Just, "Luteráni v našich zemích," 23-126. Musical life within the Lutheran churches of Prague is discussed in Bat'a, "Musical Culture of the Prague Lutherans," forthcoming.

4 See Forbelský, Royt and Horyna, Holy Infant of Prague, 30-32; Wenzel, "Konfese a chrámová architektura," pt. 2.

5 RISM $1611^{1}, 1612^{3}, 1613^{2}$.

6 See Roche, "Anthologies and the Dissemination," 10-11.

7 CZ-Pu, 59 E 9726/1-3 (olim XXXIII C 20). 
adligium written by at least five scribal hands; this contains twenty-two sacred compositions: Masses, hymns, motets and psalms. The first item is a Mass for seven voices composed by a little-known Bohemian composer, Johannes Columella Misenus, following the model of Melchior Vulpius. The other compositions are either anonymous or attributed to the Italian composers Giovanni Valentini (ca. 1582-1649) or Alessandro Gualtieri (d. 1655). The contents of the manuscript adligium are set out in Table 1.

Table 1

\begin{tabular}{|c|c|c|c|c|}
\hline Author & Title & $\begin{array}{l}\text { No. of } \\
\text { Voices }\end{array}$ & Voice Designation & Remark \\
\hline $\begin{array}{l}\text { Johannes } \\
\text { Columella } \\
\text { Misenus }\end{array}$ & $\begin{array}{l}\text { Missa super Cantate Domino Melchioris } \\
\text { Vulpii a } 7 v \text {. }\end{array}$ & 7 & & \\
\hline $\begin{array}{l}\text { Giovanni } \\
\text { Valentini } \\
\end{array}$ & Missa a 8 & 8 & Altus primi chori & $\begin{array}{l}\text { RISM V } \\
89\end{array}$ \\
\hline [Anonymous] & [Te Deum laudamus] a 8 & 8 & Altus primi chori & \\
\hline [Anonymous] & [Te Deum laudamus] a 8. Non Concertato & 8 & Altus primi chori & \\
\hline $\begin{array}{l}\text { Alessandro } \\
\text { Gualtieri }\end{array}$ & Missa pro defunctis a 8 & 8 & Altus primi chori & $\begin{array}{l}\text { RISM G } \\
4790\end{array}$ \\
\hline $\begin{array}{l}\text { Giovanni } \\
\text { Valentini } \\
\end{array}$ & [Missa] a 5 & 5 & & \\
\hline [Anonymous] & Exultate Deo adiutori nostro & $12(?)$ & $\begin{array}{l}\text { Altus secundi chori \& Altus } \\
\text { tertii chori }\end{array}$ & \\
\hline [Anonymous] & Benedicam Dominum in omni tempore & $12(?)$ & $\begin{array}{l}\text { Altus secundi chori \& Altus } \\
\text { tertii chori }\end{array}$ & \\
\hline [Anonymous] & Exultate Deo adiutori nostro & $12(?)$ & $\begin{array}{l}\text { Altus secundi chori \& Altus } \\
\text { tertii chori }\end{array}$ & \\
\hline $\begin{array}{l}\text { Giovanni } \\
\text { Valentini } \\
\end{array}$ & $\begin{array}{l}\text { Salve virtutum mare magnum, Virgo Maria } \\
\text { a } 6\end{array}$ & 6 & Altus & \\
\hline $\begin{array}{l}\text { Giovanni } \\
\text { Valentini } \\
\end{array}$ & $\begin{array}{l}\text { O quam felix est fons sanctorum, mater } \\
\text { choros angelorum a } 6\end{array}$ & 6 & & \\
\hline [Anonymous] & Vivat hospes & & & \\
\hline M. Fux & Dixit Dominus & $8(?)$ & Altus primi chori & \\
\hline [M. Fux] & Confitebor tibi Domine & $8(?)$ & Cantus secundi chori & \\
\hline [M. Fux] & Beatus vir qui timet Dominum & & & \\
\hline [M. Fux] & Laudate pueri & & & \\
\hline$[\mathrm{M} . \mathrm{Fux}]$ & Laudate Dominum omnes gentes & & & \\
\hline [Anonymous] & Mundus gaudebit & $8(?)$ & $\begin{array}{l}\text { Cantus primus \& Discantus } \\
{[!] \text { secundus }}\end{array}$ & \\
\hline [Anonymous] & Qui venerunt ex magna tribulatione & $8(?)$ & Discantus [!] secundus & \\
\hline [Anonymous] & [Missa] & & & \\
\hline [Anonymous] & O salutaris hostia & $8(?)$ & $\begin{array}{l}\text { Cantus primus \& Cantus } \\
\text { secundus }\end{array}$ & \\
\hline [Anonymous] & Confitemini Domino & & Altus & \\
\hline
\end{tabular}


The second musical source is a fragmentary set of partbooks (Altus, Bassus, Quinta, Sexta and Septima vox) preserved today in the Sächsische Landesbibliothek - Staats- und Universitätsbibliothek Dresden (D-Dl). It consists of a collection of forty-seven motets, the Cantiones sacrae de praecipuis festis totius anni 5, 6, 7, \& 8 vocum published in 1599 in Hamburg by Hieronymus Praetorius (1560-1629); its adligium manuscript contains thirteen mostly Marian devotional motets for four to ten voices, progressing from simple homophony via imitative counterpoint to a polychoral texture. ${ }^{8}$ As can be seen from Table 2, most of the compositions within the adligium, which are by Italian, German and Flemish composers, are suitable for use at Compline.

Table 2

\begin{tabular}{|l|l|c|l|}
\hline Author & Title & No. of Voices & Remark \\
\hline Jacob Handl-Gallus & Ave, Maria. Gratia plena & 6 & \\
\hline Blasius Ammon & Ave, Maria. Gratia plena & 6 & \\
\hline [Charles Luython] & Dies est laetitiae & 8 & \\
\hline [Anonymous] & Regina coeli laetare & 4 & \\
\hline [Anonymous] & Salve Regina, mater misericordiae & 8 & \\
\hline [Agostino Agazzari] & Ave, stella matutina & 8 & RISM A 330 \\
\hline Jacobus Reiner & Salve Regina & 6 & RISM R 1084 \\
\hline Giovanni Gabrieli & Iam non dicam vos servos & 8 & RISM G 86 \\
\hline [Anonymous] & Salve Regina, mater misericordiae & 6 & \\
\hline [Orpheo Vecchi] & Regina caeli laetare & 5 & RISM V 1057 \\
\hline Orpheo Vecchi & Alma Redemptoris Mater & 5 & RISM V 1057 \\
\hline [Orpheo Vecchi] & Ave, Regina coelorum & 5 & RISM V 1057 \\
\hline [Anonymous] & Beata es, virgo Maria, Dei genitrix & \\
\hline
\end{tabular}

This convolute originally belonged to the Jesuit Marian confraternity in the Old Town of Prague based at the Collegium Clementinum, founded in 1575. This confraternity was patterned on the Congregatio Divae Barbarae at the Jesuit college in Vienna. Its constitution imposed firm rules on its members: besides the obligation of daily attendance at Mass and the recitation of prayers from the Breviary and the Rosary, members of the confraternity had to assemble during Saturday Vespers and Marian feasts to sing Litanies. The growing importance of the confraternity is shown by the lists of applicants for membership, among whom were members of the intellectual and social elite; these applicants included members of the imperial court and indeed imperial musicians such as the organist Paulus de Winde, the assistant leader of the court music ensemble, Matthias de Sayve, and Jacob Regnart. ${ }^{9}$

The question now arises: what do these two musical sources have in common? At this point our story begins. Its protagonist is the Bohemian Humanist and musician, Nicolaus

8 D-D1, Mus. Pi 2. See Steude and Kümmerling, Die Musiksammelhandschriften, 180.

9 The Jesuit confraternities in general are discussed in Lazar, Working in the Vineyard of the Lord. The attitude to music of the Prague confraternity is described in Bata, "Jesuité a hudební kultura předbělohorské Prahy," 977-983. 
Dionysius. He was probably born in 1577 in Beroun, a royal city in central Bohemia. He accordingly adopted as his cognomen "Beronensis." We know nothing about his childhood, youth, or education, but it is certain that he was well instructed in music and in Latin. Dionysius was probably a student at the Charles University in Prague (although he did not graduate); from 1599 to 1601 he worked at a school in Louny, a royal city in north-west Bohemia. After this short period as a schoolteacher he returned to Prague and entered the service of the city council of the Old Town. In 1605 he obtained the citizenship of Prague and two years later was given the noble title "a Doubravína," although this honour brought him no more than a coat of arms. Thanks to an advantageous marriage, Nicolaus Dionysius acquired property, which enabled him to achieve a higher social status. ${ }^{10}$ His musical activities were mainly connected with the Lutheran community of the Old Town of Prague. This community, however, did not have its own church until Sunday, 5 October 1614, when, as already stated, the Lutheran Church of the Holy Saviour near the Old Town Square was solemnly opened. Until then Lutherans had needed to hire various Utraquist churches in Prague. Dionysius served as the regens chori, and the Church of the Holy Saviour was most probably the place where he employed the convolute of Promptuarium musicum that bears his supralibros $N D B A D$ on its binding.

It appears that Dionysius was only a performing musician, not a composer; nevertheless he penned many literary texts and poems in Czech and Latin, among them several song texts. ${ }^{11}$ One of the Latin poems evidences his relationship not only to the community of Humanist poets but also to that of musicians. It was written as an epitaph for Paulus Spongopaeus Jistebnicenus, the most prolific Czech composer of the time, who died in Kuttenberg in 1619. Dionysius shows his poetic and musical skills by employing the voces musicales ut - re - mi - fa - sol - la both as an acrostic and as a telestic. ${ }^{12}$

The adult life of Nicolaus Dionysius was deeply influenced by politics. The defenestration of the vice-regents of Bohemia from the windows of Prague Castle on 23 May 1618 sparked a rebellion of the Bohemian Protestant Estates against the Habsburg dynasty. The government established by the rebels took the form of a thirty-member directorate with equal representation from lords, knights and towns. King Ferdinand II was dethroned, and one year later, on 26 August 1619, the rebels voted in his stead Frederick V, the Elector Palatine, who entered into history as the "Winter King." ${ }^{13}$ On 31 October 1619 Frederick entered Prague with great pomp and ceremony, Nicolaus Dionysius welcoming the new king at the city gates with a Latin poem. However, Dionysius paid painfully for this fleeting moment of glory during the so-called Prague execution of June 1621.

The rebellion brought about many changes in the political, social and cultural life of

${ }^{10}$ For a more detailed survey of his life and works, see Sokol, Mikuláš Diviš; Truhlář et al., Rukovět' humanistického básnictví, 48-49.

${ }^{11}$ Most of his texts are preserved in an autograph manuscript held by the Christian-Weise-Bibliothek Zittau, Wissenschaftlicher und Heimatgeschichtlicher Altbestand. See D-ZI, $4^{\circ}$ B 25. The manuscript has been partially edited in Sokol, Mikuláš Diviš, 45-80.

${ }^{12}$ See Prague, Knihovna Národního muzea (CZ-Pn), Ms. V D 6/II, p. 216, http://www. manuscriptorium.com/apps/main/en/index.php?request=quick_search\&param $=\&$ client $=\&$ ats $=1426008497 \&$ mode $=\&$ testMode $=\& s f \_q u e r y L i n e=V . D .6 \% 2 F 2 \&$ qs_field $=6$.

${ }^{13} \mathrm{He}$ spent only one winter on the throne. 
the Czech kingdom. The most important event from our point of view is the expulsion of the Jesuit order from the Czech Lands in summer 1618. The Collegium Clementinum and its library were confiscated and given to the Charles University. The university authorities were fortunate to absorb the library of their rivals into their own, but they lacked an original inventory of the Jesuits' books. One of the persons who made a catalogue of the confiscated library was the preacher of the Lutheran Church of the Holy Saviour, Fabianus Natus (1591-1634). ${ }^{14}$ Natus was not paid for this work and accordingly decided to reward himself. He took several books from the Clementinum College library with him to the Lutheran church. ${ }^{15}$ The convolute belonging to the Jesuit Marian confraternity was most probably among them; it was given to the organist, who used it for a certain time. The character of the music performed in the Lutheran church of the Holy Saviour in the Old Town of Prague was during those years mostly influenced by the double-choir technique common to Protestant and Catholic composers. ${ }^{16}$

The two-year rebellion of the Protestant Estates against the Habsburg dynasty ended in a two-hour battle at White Mountain near Prague on 8 November 1620. The defeat of the Protestants was disastrous. Frederick, the "Winter king," escaped from the country and left the Kingdom of Bohemia defenceless. Ferdinand II mounted the throne again and began a great trial of the rebels. Many people were imprisoned, Nicolaus Dionysius among them. The final verdict was merciless: on 21 June 1621, twenty-seven leaders of the opposition from the Estates were executed in the Old Town Square in Prague. ${ }^{17}$

Even though Nicolaus Dionysius was not condemned to death, his punishment was cruel. On 22 June 1621 his tongue was nailed for two hours to the gallows in the Old Town. ${ }^{18} \mathrm{He}$ was then imprisoned for two further years. His imprisonment served, Nicolaus Dionysius was released. However, political and religious life beyond the walls of the Old Town prison had in the meantime changed. Protestant priests were expelled from the city and country, starting in 1622. Inevitably, the Lutheran Church of the Holy Saviour was closed. Dionysius remained in the city until 1627, when Ferdinand II issued a new constitution for the Kingdom of Bohemia - the so-called Renewed Land Ordinances. Beyond its declaration of a hereditary accession to the Bohemian throne and other important legal changes, the Renewed Land Ordinances demanded the conversion to Catholicism of all the Protestant inhabitants of the Czech Lands. Like other Protestants, Nicolaus Dionysius had a choice: to remain and convert, or to go into exile. ${ }^{19}$ Dionysius chose the second path and moved with all his family and belongings to the city of Pirna in Saxony, where he

${ }^{14}$ For an overview of Natus' life and works, see Truhlář et al., Rukovět humanistického básnictví, 11-13.

15 Tobolka and Horák, Národní a universitni knihovna v Praze, 38-39.

${ }^{16}$ The confessional neutrality of this style assisted the migration of the repertory between the different denominations.

17 See Pánek et al., History of the Czech Lands, 233-234.

${ }^{18}$ Dionysius described in detail all his sufferings during that period in a Latin tract Actus martyrologicus, written in the above-mentioned manuscript held by the Christian-WeiseBibliothek in Zittau. This tract inspired a novel by Jan Blahoslav Čapek, Za jazyk přibitý, printed in Prague in 1970.

${ }^{19}$ See Pánek et al., History of the Czech Lands, 234-235. 
became organist at the Church of St Nicholas, which had been made over to Bohemian immigrants. ${ }^{20}$ The music in the Jesuit partbooks probably saw use in the devotional services celebrated by this community.

In the following years the military situation of the Thirty Years' War altered in favour of the Protestants. In 1631 a Saxon army invaded Bohemia and occupied Prague until the spring of $1632 .{ }^{21}$ Many Protestant refugees, including Dionysius, returned to Prague and renewed their religious services. The Church of the Holy Saviour, which was now Catholic, was confiscated and became Lutheran once again; however, this new situation did not continue for long. During the spring of 1632 Albrecht von Wallenstein, as supreme commander of the Catholic Habsburg armies, recaptured the lost Bohemian territories, and the Protestants were forced to leave Bohemia for good. Nicolaus Dionysius was imprisoned once more and then released. Finally, on 4 January 1636, he was expelled from Prague and Bohemia, dying in Leszno, Poland, in 1647.

In this article I have offered an explanation of how the Jesuit convolute found its way to Pirna in Saxony. The itinerary traversed by the alto partbook of Promptuarium musicum is not so clear. It is evident that Nicolaus Dionysius left it behind in Prague, but we can only hazard a guess whether this occurred after his first expulsion in 1627 or some nine years later. The convolute was bound in 1617 and Dionysius inserted several sheets of paper at the end by way of later additions. The music manuscript paper bears only one watermark, of originally Styrian provenance, which can be dated to Prague ca. 1600.22 Dionysius wrote out only the first composition by Columella Misenus, leaving the rest was blank. When the Jesuits gained possession of the convolute, they started to fill the empty space with polychoral works by the early baroque composers Giovanni Valentini and Alessandro Gualtieri, plus other, still unidentified masters. The exlibris Templi Societatis Jesu Neopragae on the title page was affixed there somewhat later, since construction of the church of St Ignatius in the New Town of Prague began only in 1665 .

The repertory of the two sources discussed in this article attests the homogeneity and confessional neutrality of polychoral music at the beginning of the seventeenth century. The convolute of the Jesuit Marian confraternity combining a collection of motets by the Lutheran Hieronymus Praetorius with Marian devotional compositions found its way initially to the Lutheran church of the Holy Saviour, and later to the exiles in Pirna, Saxony. Conversely, the Lutheran collection, augmented by its polychoral repertory taken from the circles around the Habsburg court, served well in this Catholic milieu for several decades. Today, the physical distance of the two sources can be seen as symbolic: despite sharing a common musical language, Lutherans and Catholics were divided by confessional and political barriers.

${ }^{20}$ Lists of immigrants from Prague and north-west Bohemia are compiled in Bobková, Exulanti z Prahy.

${ }^{21}$ See Rezek, Déjiny saského vpádu.

${ }^{22}$ Briquet, Les Filigranes, no. 1918: Prague 1591-1604; var. Prague 1600, Vienna 1606. 


\section{Sources}

Dresden, Sächsische Landesbibliothek - Staats- und Universitätsbibliothek (D-Dl), Mus. Pi 2. Prague, Národní knihovna České republiky (CZ-Pu), 59 E 9726/1-3 (olim XXXIII C 20). Prague, Knihovna Národního muzea (CZ-Pn), V D 6/II.

Zittau, Christian-Weise-Bibliothek, Wissenschaftlicher und Heimatgeschichtlicher Altbestand (D-ZI), $4^{\circ} \mathrm{B} 25$.

\section{Bibliography}

Bat’a, Jan. “Jesuité a hudební kultura předbělohorské Prahy: Glosy ke vzájemné interakci na př́ikladu klementinské mariánské sodality.” In Bohemia jesuitica 1556-2006, vol. 2, edited by Petronilla Čemus, 977-983. Prague: Karolinum, 2010.

"Musical Culture of the Prague Lutherans in the Period before the Battle of White Mountain.” In The Bohemian Reformation and Religious Practice, vol. 10, edited by Zdeněk V. David et al. Prague: Filosofia, 2015 (forthcoming).

Bobková, Lenka. Exulanti z Prahy a severozápadních Čech v Pirně v letech 1621-1639. Prague: Scriptorium, 1999.

Briquet, Charles-Moïse. Les Filigranes: Dictionnaire historique des marques du papier des leur apparition vers 1282 jusqu'en 1600. 4 vols. Leipzig: K. W. Hiersemann, 1923.

Čapek, Jan Blahoslav. Za jazyk přibitý. Prague: Melantrich, 1970.

David, Zdeněk V. Finding the Middle Way: The Utraquists' Liberal Challenge to Rome and Luther. Washington, DC: Woodrow Wilson Center Press, 2003.

Forbelský, Josef, Jan Royt and Mojmír Horyna. The Holy Infant of Prague. Prague: Aventinum, 1992.

Just, Jiříi. “Luteráni v našich zemích do Bílé hory.” In Luteráni v českých zemích v proměnách staletí, edited by Jiří Just et al., 23-126. Prague: Lutherova společnost, 2009.

Lazar, Lance Gabriel. Working in the Vineyard of the Lord: Jesuit Confraternities in Early Modern Italy. Toronto: University of Toronto Press, 2005.

Pánek, Jaroslav, Oldřich Tůma et al. A History of the Czech Lands. Prague: Karolinum Press, 2009.

Rezek, Antonín. Dějiny saského vpádu do Čech (1631-1632) a návrat emigrace. Prague: I. L. Kober, 1889.

Roche, Jerome. "Anthologies and the Dissemination of Early Baroque Italian Sacred Music." Soundings 4 (1974): 6-12.

Schreiber, Rudolf. Das Spenderbuch für den Bau der protestantischen Salvatorkirche in Prag (1610-1615). Freilassing: O. Müller, 1956.

Sokol, Vojtěch. Mikuláš Diviš z Doubravína. Prague: Královská česká společnost nauk, 1932.

Steude, Wolfram, and Harald Kümmerling. Die Musiksammelhandschriften des 16. und 17. Jahrhunderts in der Sächsischen Landesbibliothek zu Dresden. Leipzig: VEB Deutscher Verlag für Musik, 1974.

Tobolka, Zdeněk Václav, and František Horák. Národní a universitní knihovna v Praze, její vznik a vývoj. Počátky knihovny až do roku 1777. Prague: SPN, 1959. 
Truhlár̆, Antonín, et al., eds. Rukovět humanistického básnictví v Čechách a na Moravě = Enchiridion renatae poesis Latinae in Bohemia et Moravia cultae. 6 vols. Prague: Academia, 1966-2011.

Wenzel, Kai. "Konfese a chrámová architektura: Dva luteránské kostely v Praze v předvečer třicetileté války." Pts. 1 and 2. Pražský sborník historický 36 (2008): 31-103; 37 (2009): 7-66. 


\section{MED PRAGO IN PIRNO \\ ZGODBA IZ ČASA ZAČETKA TRIDESETLETNE VOJNE}

\section{Povzetek}

Razprava obravnava dva polifona glasbena vira s preloma 16. v 17. stoletje (CZ-Pu, 59 E 9726/1-3 (olim XXXIII C 20) in D-Dl, Mus. Pi. 2). Oba vira sta povezana s češkim humanistom in glasbenikom Nicolausom Dionysiusom (ok. 1577-1647), ki so ga leta 1627 zaradi njegovega luteranskega prepričanja pregnali iz Češke v Pirno.

Prvi vir predstavlja sveženj treh altovskih glasovnih zvezkov zbirke Promptuarium musicum (RISM 1611 ${ }^{1}, 1612^{3}, 1613^{2}$ ), ki jo je pripravil kantor v mestu Speier Abraham Schadeus (1566-1626). Sveženj, ki je nekoč pripadal omenjenemu Nicolausu Dionysiusu, se sedaj nahaja v Glasbenem oddelku Narodne knjižnice Republike Češke v Pragi. Vsebuje tudi privezane strani z rokopisnimi dodatki, ki jih je pisalo vsaj pet zapisovalcev. Na teh straneh najdemo 22 cerkvenih skladb (maše, himnuse, motete in psalme) več avtorjev: od malo znanega češkega skladatelja Johannesa Columella Misenusa pa do Giovannija Valentinija (ok. 1582-1649) in Alessandra Gualtierija (u. 1655).

Drugi vir je nepopolno ohranjen set glasovnih zvezkov zbirke motetov s privezi, ki so danes shranjeni v Saški deželni, državni in univerzitetni knjižnici (D-Dl) v Dresdnu. 47 motetov zbirke Cantiones sacrae de praecipuis festis totius anni 5, 6, 7, \& 8 vocum je leta 1599 v Hamburgu objavil Hieronymus Praetorius (1560-1629), v rokopisnih dodatkih pa je še 13 pretežno marijanskih motetov za štiri do deset glasov; po zvočnosti obsegajo vse od preproste homofonije do zapletene polifonije in večzborja. Prvotno je ta skupina glasovnih zvezkov pripadala jezuitski marijanski družbi v starem mestu in leta 1575 ustanovljenemu kolegiju Clementinum v Pragi.

Jezuitska skupina muzikalij je prišla v roke Nicolausa Dionysiusa verjetno poleti leta 1618, ko so knjižnico kolegija Clementinum zasegli protestanti. Leta 1627 se je moral ob rekatolizaciji Češkega kraljestva Dionysius z vso družino in imetjem iz Prage preseliti v mesto Pirna na Saškem, kjer je postal organist cerkve sv. Nikolaja, ki jo je mesto poklonilo češkim emigrantom.

Po drugi strani pa vse kaže, da je Dionysius v Pragi pustil svojo lastno zbirko treh altovskih glasovnih zvezkov zbirke Promptuarium musicum, ki je na koncu prešla v last jezuitov; ti so tudi porabili privezane prazne strani in jih napolnili z večglasnimi skladbami večzborskih del zgodnjebaročnih mojstrov Giovannija Valentinija in Alessandra Gualtierija.

Ta nenavadna zamenjava virov priča o glasbeni homogenosti in konfesionalni nevtralnosti večzborske glasbe začetka 17. stoletja. Še posebno zanimiv je vir iz jezuitske marijanske bratovščine, v katerem so združeni moteti protestanta Hieronymusa Praetoriusa in marijanske duhovne skladbe, nahajal pa se je najprej v luteranski cerkvi sv. Odrešenika potem pa v saški Pirni. Sicer pa je tudi protestantska zbirka - skupaj z dodanim večzborskim repertoarjem glasbenega kroga habsburške dvorne kapele - še dolga desetletja odlično služila tudi katoliškim krogom. 